\title{
Glucose and pyruvate metabolism in preimplantation blastocysts from normal and diabetic rats
}

\author{
E. Dufrasnes, I. Vanderheyden, D. Robin, J. Delcourt, S. Pampfer \\ and R. De Hertogh*
}

Physiology of Human Reproduction Research Unit, University of Louvain, School of Medicine, UCL $5330-A v$ E. Mounier 53, 1200 Brussels, Belgium

\begin{abstract}
Glucose metabolism was analysed in day- 5 rat blastocysts incubated in the presence of $\left[5-{ }^{3} \mathrm{H}\right]-$, $\left[6-{ }^{14} \mathrm{C}\right]$ - or $\left[\mathrm{U}-{ }^{14} \mathrm{C}\right]$ glucose. Glycolysis, quantified by ${ }^{3} \mathrm{H}_{2} \mathrm{O}$ recovery rate, was the main pathway of glucose utilization by fresh $\left(11.5 \pm 0.36 \mathrm{pmol}\right.$ per embryo $\left.\mathrm{h}^{-1}\right)$ or cultured $(24 \mathrm{~h})$ blastocysts $\left(20.4 \pm 0.6 \mathrm{pmol}\right.$ per embryo $\left.\mathrm{h}^{-1}\right)$. Glucose consumption rate was almost saturated at a medium glucose concentration of $0.28 \mathrm{mmol}^{-1}\left(K_{\mathrm{m}}: 0.17 \mathrm{mmol}^{-1} ; V_{\max }\right.$ : 23 pmol per embryo $h^{-1}$ ). A further $10 \%$ increase in glucose utilization was obtained with a tenfold higher glucose concentration $\left(3 \mathrm{mmoll}^{-1}\right)$. Phloretin completely abolished the rapid component of glucose utilization kinetics, suggesting the existence of a $\mathrm{Na}^{+}$-independent glucose transport system. Less than $1 \%$ of $\left[6{ }^{14} \mathrm{C}\right]$ glucose consumed by cultured blastocysts was oxidized through the Krebs cycle. $\left[1-{ }^{14} \mathrm{C}\right]$ pyruvate, however, was oxidized at a rate of 2 pmol per embryo $h^{-1}$ by fresh blastocysts. The pentose-phosphate pathway accounted for about $2 \%$ of glucose utilization. One to two per cent of the total glucose metabolized in $24 \mathrm{~h}$ was retained in macromolecules. Insulin had no effect on glucose uptake, utilization, incorporation and turnover, or on pyruvate oxidation. Blastocysts from diabetic mothers utilized glucose at a rate similar to that of normal blastocysts. These results show that glucose is actively taken up by rat blastocysts and utilized mainly through the Embden-Meyerhof pathway, which is rapidly saturated at low glucose concentrations. Retention of glucosederived products in macromolecules, although relatively small, may modulate the effect of high glucose concentrations on embryo growth. The lack of effect of insulin on the main metabolic pathways of glucose metabolism does not rule out a more discrete insulin effect at some molecular levels.
\end{abstract}

\section{Introduction}

Experimental diabetes induced in rodents by streptozotocin or alloxan administration before pregnancy provokes an increased incidence of congenital malformations in the offspring (Eriksson, 1984). Besides the deleterious effect of matemal diabetes on early fetal organogenesis, recent observations by ourselves in rats (De Hertogh et al., 1989, 1992; Pampfer et al., 1990; Vercheval et al., 1990), and by others in mice (Diamond et al., 1989; Beebe and Kaye, 1991) have shown that embryo growth is already impaired at the preimplantation stage, mainly at the expense of the inner cell mass of the blastocysts (Pampfer et al., 1990). Moreover, in vitro experiments demonstrated that high glucose concentrations and high insulin concentrations in the presence of glucose can impair rat blastocyst development, whereas low insulin concentrations stimulate growth of the inner cell mass (De Hertogh et al., 1991). Insulin stimulates protein and nucleic acid synthesis (Harvey and Kaye, 1988; Heyner

*Correspondence and reprint requests.

Received 15 June 1992 et al., 1989) and growth of the inner cell mass (Harvey and Kaye, 1990) in mouse blastocysts, in which insulin receptors have been reported (Rosenblum et al., 1986).

Preimplantation mouse embryos shift from predominantly using pyruvate to glucose at the late morula and early blastocyst stages (Leese and Barton, 1984; Brown and Whittingham, 1991). This shift has recently been confirmed in rat preimplantation embryos, by measuring substrate consumption and lactate production with a noninvasive method (Brison and Leese, 1991). However, glucose metabolic pathways have not yet been described in the rat blastocyst. It has been suggested (Gardner and Kaye, 1984) but not confirmed (Gardner and Leese, 1988) that, in mice, insulin acts on glucose uptake or incorporation into preimplantation blastocysts.

In view of the recent observations made on preimplantation embryos from diabetic rats, and on the interplay of glucose and insulin on blastocyst growth in in vitro cultures, we decided to analyse the different pathways of glucose metabolism and the effect of insulin on glucose consumption, incorporation and retention in fresh and cultured rat blastocysts. 


\section{Materials and Methods}

\section{Animals, blastocyst retrieval and culture}

Ten- to twelve-week-old female Wistar rats from the University breeding centre were mated overnight with males. The presence of a vaginal plug on the following morning was considered as day 1 of pregnancy. On the morning of day 5, pregnant rats were submitted to light ether anaesthesia, the uterine horns removed and the embryos retrieved by gentle flushing with $0.5 \mathrm{ml}$ prewarmed glucose-free Ham's F-10 medium (07400088 , Gibco, Grand-Island, NY) containing $1 \mathrm{~g} \mathrm{BSA} \mathrm{l^{-1 }}$ (A 9647, Sigma, St Louis, MO). Blastocysts, characterized by the presence of a clear blastocoel, were either put in metabolic chambers (fresh embryos), or transferred to incubating cells (Multidish, Nunc, Intermed, Roskilde, Denmark), and cultured for $24 \mathrm{~h}$ in Ham's F-10 medium, containing 6 mmol glucose $\mathrm{l}^{-1}$, $100 \mathrm{iu}$ penicillin $\mathrm{ml}^{-1}$ and $100 \mu \mathrm{g}$ streptomycin $\mathrm{ml}^{-1}$ with or without added purified bovine insulin (Gibco) at a concentration of $600 \mathrm{pmol} \mathrm{I}^{-1}$ as previously described (De Hertogh et al., 1991). At the end of the incubation period, embryos were recovered and transferred to metabolic chambers (cultured embryos).

Diabetic rats were obtained by injecting streptozotocin $\left(50 \mathrm{mg} \mathrm{kg}^{-\mathrm{I}}\right.$ ) to fasted rats as described by De Hertogh et al. (1982) and Vercheval et al., (1990). Diabetes was confirmed after $24 \mathrm{~h}$ by the presence of high glycosuria and a blood glucose concentration exceeding $14 \mathrm{mmol}^{-1}$. Diabetic animals were mated one to three weeks after the onset of diabetes. On day 5 of pregnancy, the diabetic state of the mother was confirmed and embryos were recovered as described above. Fully formed blastocysts only were used for metabolic studies.

\section{Metabolic studies}

The metabolic chamber was similar to that described by O'Fallon and Wright (1986). In brief, it consisted of a $1.5 \mathrm{ml}$ tube containing $1 \mathrm{ml} 0.1 \mathrm{~mol} \mathrm{NaOH} 1^{-1}$. The embryos were suspended in a $5 \mu \mathrm{l}$ microdrop of glucose-free Ham's F-10-BSA medium, enriched with Hepes $\left(6 \mathrm{gl}^{-1}\right)$ and the appropriate metabolic substrate (see below), from the inside surface of the cap, which was then gently fixed on the top of the tube. The tubes were incubated at $37^{\circ} \mathrm{C}$ for $4 \mathrm{~h}$. At the end of the incubation time, the $\mathrm{NaOH}$ was quantitatively transferred to a counting vial containing $15 \mathrm{ml}$ of scintillation mixture (Instagel, Packard Instrument, Groningen) and radioactivity was measured (Tri-Carb 4000, Packard). A correction was made for radioactivity measured in a blank metabolic chamber containing the same metabolic substrate but no embryo in the suspended microdrop.

Experiments allowed the measurement of glucose utilization by the main metabolic pathways ( $\mathrm{O}^{\prime}$ Fallon and Wright, 1986, 1987). Hence, $\left[5-{ }^{3} \mathrm{H}\right]-$, $\left[\mathrm{U}-{ }^{14} \mathrm{C}\right]$ - or $\left[6-{ }^{14} \mathrm{C}\right] \mathrm{glucose}$ or $\left[1-{ }^{14} \mathrm{C}\right]$ pyruvate were included in the Ham's F10-Hepes medium at different concentrations, in the presence or absence of insulin. In all experiments, labelled glucose or pyruvate concentrations are expressed in mmol $\mathrm{l}^{-1}$ of total substrate, taking into account the concentration of unlabelled compound present or added to the incubation medium.

From preliminary experiments measuring the kinetic equilibrium between $5 \mu \mathrm{l}$ microdrops of ${ }^{3} \mathrm{H}_{2} \mathrm{O}$ suspended in metabolic chambers and $\mathrm{NaOH}$ layers, it was concluded that $82 \%{ }^{3} \mathrm{H}_{2} \mathrm{O}$ released by embryos during a $4 \mathrm{~h}$ period was quantitatively recovered in the $\mathrm{NaOH}$ layers. Similar experiments performed with $5 \mu \mathrm{l}$ microdrops of Ham's F- 10 medium containing a tracer amount of $\left[{ }^{14} \mathrm{C}\right]$ bicarbonate indicated that about $76 \%$ of ${ }^{14} \mathrm{CO}_{2}$ produced by embryos during $4 \mathrm{~h}$ would be recovered. A correction for recovery has therefore been included in the results. A linear relationship between ${ }^{14} \mathrm{CO}_{2}$ recovery and time of incubation or number of embryos in the metabolic chambers was observed. The results of the metabolic studies were therefore expressed in terms of pmol of total substrate (labelled and unlabelled) consumed per embryo $\mathrm{h}^{-1}$.

\section{Glucose incorporation and retention}

Glucose incorporated into blastocysts by the end of the incubation in the presence of $\left[{ }^{3} \mathrm{H}\right]-$ or $\left[{ }^{14} \mathrm{C}\right]$ glucose was measured. Embryos were recovered from the metabolic milieu and quickly washed six times in Earle's medium (EBSS, Gibco), supplemented with $5 \mathrm{mmol}$ sodium pyruvate $\mathrm{l}^{-1}$ and $1 \mathrm{mmol}$ L-glutamine $\mathrm{l}^{-1}$. Embryos were then digested in $500 \mu \mathrm{l}$ soluene (Packard) for $24 \mathrm{~h}$, and radioactivity measured in $10 \mathrm{ml}$ ionic fluor (Packard). The retention of the incorporated label was studied by pulsechase experiments in which the embryos, after washing, were further incubated for several hours in the original medium, in which unlabelled glucose was substituted for $\left[{ }^{3} \mathrm{H}\right]$ - or $\left[{ }^{14} \mathrm{C}\right]$ labelled compound. At the end of the incubation period, the embryos were recovered, digested in soluene and counted. Concentrations of incorporated and retained substances are expressed as pmol per embryo, taking into account the specific activity of glucose in the culture medium.

\section{Chemicals}

Phloretin (Sigma) was used to block $\mathrm{Na}^{+}$-independent glucose transport. Phenazine ethosulfate (Sigma), which oxidizes NADPH to $\mathrm{NADP}^{+}$, was used to stimulate the pentose-phosphate shunt. Dinitrophenol (Sigma), uncouples oxidative phosphorylation, and was used to stimulate Krebs cycle (Rieger and Guay, 1988). $\left[6-{ }^{14} \mathrm{C}\right]$ glucose (50 to $60 \mathrm{mCi} \mathrm{mmol}^{-1}$; Amersham, UK) was used to measure glucose oxidation through the Krebs cycle, on the basis of a one to one molar ratio between ${ }^{14} \mathrm{CO}_{2}$ recovered and $\left[6-{ }^{14} \mathrm{C}\right]$ glucose oxidized. $\left[\mathrm{U}^{-14} \mathrm{C}\right.$ glucose $\left(>230 \mathrm{mCi} \mathrm{mmol}{ }^{-1}\right.$; Amersham, UK) was used to estimate the Krebs cycle and pentose-phosphate shunt. In the latter pathway, one mole of glucose was considered to yield three moles of ${ }^{14} \mathrm{CO}_{2}$ after complete recycling.

$\left[1{ }^{14} \mathrm{C}\right]$ pyruvate $\left(32 \mathrm{mCi} \mathrm{mmol}^{-1}\right.$; Amersham, UK) was used to measure the activity of the pyruvate dehydrogenase complex and of the Krebs cycle, on the basis of a one to one molar ratio between the ${ }^{14} \mathrm{CO}_{2}$ produced and the pyruvate oxidized. Finally, $\left[5-{ }^{3} \mathrm{H}\right]$ glucose ( 10 to $20 \mathrm{mCi} \mathrm{mmol}^{-1}$; Amersham, UK) allowed the measurement of the glycolytic pathway, assuming a one to one molar ratio between ${ }^{3} \mathrm{H}_{2} \mathrm{O}$ produced and $\left[5-{ }^{3} \mathrm{H}\right]$ glucose metabolized.

\section{Statistical analysis}

Two-tailed unpaired $t$ tests were used to determine the significance of differences between experimental groups. 
Table 1. Glucose utilization by fresh and cultured day-5 rat blastocysts in the presence and absence of insulin

\begin{tabular}{|c|c|c|c|c|}
\hline \multirow{2}{*}{$\begin{array}{l}\text { Insulin } \\
\text { concentration } \\
\left(\text { pmol } 1^{-1}\right)\end{array}$} & \multicolumn{2}{|c|}{$\begin{array}{c}{\left[5-^{3} \mathrm{H}\right] \text { glucose } e^{\mathrm{a}}} \\
\text { (pmol per embryo } \mathrm{h}^{-1} \text { ) }\end{array}$} & \multicolumn{2}{|c|}{$\begin{array}{c}{\left[\mathrm{U}-{ }^{14} \text { C]glucose } \mathrm{e}^{\mathrm{a}, e}\right.} \\
\left(\text { pmol per embryo } \mathrm{h}^{-1} \text { ) }\right.\end{array}$} \\
\hline & $\begin{array}{l}\text { Fresh } \\
\text { embryos }\end{array}$ & $\begin{array}{l}\text { Cultured } \\
\text { embryos }\end{array}$ & $\begin{array}{l}\text { Fresh } \\
\text { embryos }\end{array}$ & $\begin{array}{l}\text { Cultured } \\
\text { embryos }\end{array}$ \\
\hline 0 & $11.5 \underset{(7)^{\mathrm{d}}}{ \pm} 0.36$ & $20.4 \pm \underset{(48)}{ \pm 0.6 *}$ & $0.29 \pm 0.01$ & $0.46 \underset{(52)}{ \pm} 0.02^{*}$ \\
\hline $600^{b}$ & $12.0 \pm \frac{ \pm}{(6)} 0.36$ & $19.2 \underset{(52)}{ \pm} 0.84^{*}$ & $0.29 \pm 0.01$ & $0.42 \underset{(58)}{ \pm 0.02^{*}}$ \\
\hline $600^{\mathrm{c}}$ & $12.0 \pm 0.36$ & $\begin{array}{c}19.2 \pm 0.5^{*} \\
(47)\end{array}$ & $0.29 \pm \underset{(16)}{0} 0.01$ & $0.42 \pm \underset{(50)}{ \pm 0.02^{*}}$ \\
\hline
\end{tabular}

\footnotetext{
Values given as means \pm SEM.

${ }^{a}$ Glucose concentration was $0.28 \mathrm{mmol} \mathrm{I}^{-1}$ throughout the $4 \mathrm{~h}$ incubation.

'Insulin was present throughout the culture $(24 \mathrm{~h})$ and incubation $(4 \mathrm{~h})$.

Insulin was present during the incubation only $(4 \mathrm{~h})$.

Numbers in parentheses are the number of metabolic chambers of three embryos each

eResults calculated on the assumption that all ${ }^{14} \mathrm{CO}_{2}$ was produced via the pentose-phosphate pathway

and that complete recycling had occurred (see text).

${ }^{*} P<0.001$ versus fresh embryos.
}

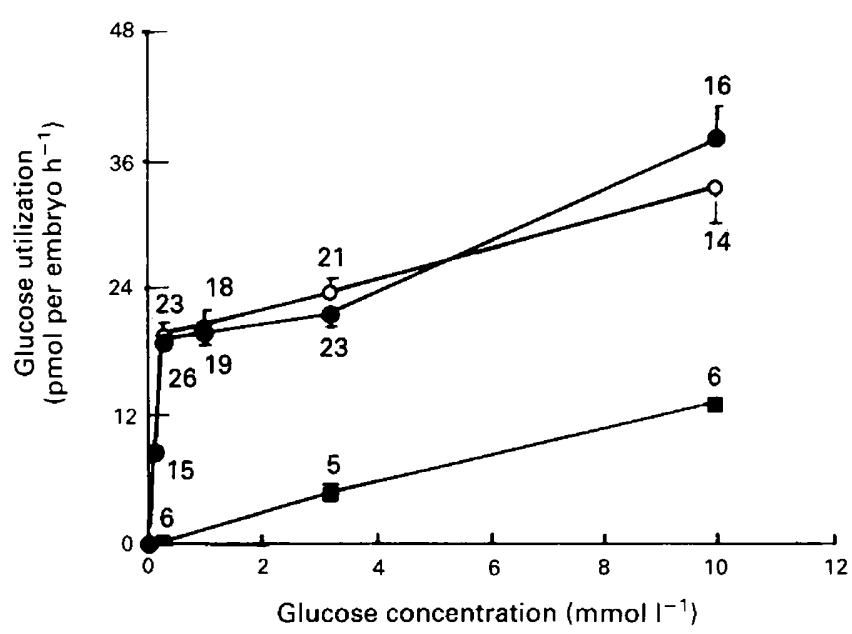

Fig. 1. Glucose utilization by day-5 rat blastocysts, cultured for $24 \mathrm{~h}$ and further incubated in the presence of $\left[5-{ }^{3} \mathrm{H}\right]$ glucose at increasing concentrations for $4 \mathrm{~h}$, with $(\mathrm{O})$ or without $(1)$ insulin $\left(600 \mathrm{pmol}^{-1}\right)$ or phloretin ( $)\left(0.5 \mathrm{mmol} \mathrm{l}^{-1}\right)$. Each point is the mean \pm SEM of indicated numbers of cells incubated from three embryos.

\section{Results}

\section{$\left[5-{ }^{3} \mathrm{H}\right] g l u c o s e$ utilization}

At a concentration of $0.28 \mathrm{mmol}^{-1}$, overall glucose utilization through glycolysis amounted to 11.5 pmol per embryo $\mathrm{h}^{-1}$ in fresh, day 5 blastocysts, and to 20.4 pmol per embryo $\mathrm{h}^{-1}$ in blastocysts cultured for $24 \mathrm{~h}$ (Table 1 ). Insulin had no effect on these utilization rates.

Kinetic studies showed a curvilinear relationship between glucose utilization by cultured embryos and glucose concentration, with a sharp increase up to $0.28 \mathrm{mmol}^{-1}$, and a slow linear increase at higher concentrations (Fig. 1). Insulin had no

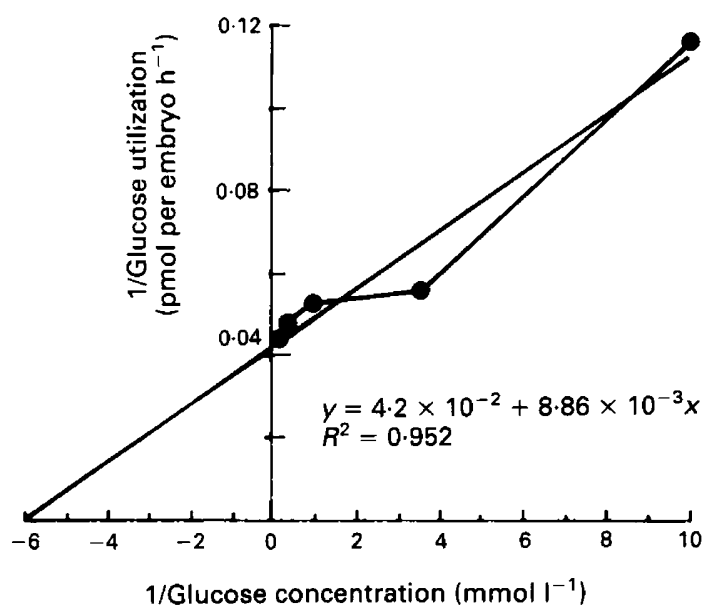

Fig. 2. Double reciprocal plot of the rapid component of glucose utilization (from Fig. 1) versus glucose concentration. The intercept on the $y$ axis is $1 / V_{\max }$. The slope of the curve is $K_{\mathrm{t}} / V_{\max }$.

effect on the kinetic profile. Phloretin $\left(0.5 \mathrm{mmol} \mathrm{l}^{-1}\right)$ abolished the rapid utilization phase at low glucose concentration (Fig. 1). By subtracting the slow glucose utilization phase from the total utilization rate, the rapid component could be isolated and analysed on a double reciprocal plot (Fig. 2). From such a plot, the mean maximal velocity for glucose utilization $\left(V_{\max }=1 /\right.$ intercept on the $y$ axis), and the mean apparent $K_{t} / V_{\max }$ being the slope of the line) were found to be 23 pmol per embryo $h^{-1}$ and $0.17 \mathrm{mmoll}^{-1}$, respectively.

\section{$\left[\mathrm{U}-{ }^{14} \mathrm{C}\right]$ - and $\left[6-{ }^{14} \mathrm{C}\right] \mathrm{glucose}$ utilization}

${ }^{14} \mathrm{CO}_{2}$ produced from $\left[6-{ }^{14} \mathrm{C}\right]$ glucose was about 150 times lower than from $\left[\mathrm{U}^{14} \mathrm{C}\right]$ glucose (Table 2). On the assumption 
Table $2 .{ }^{14} \mathrm{CO}_{2}$ production from $\left[\mathrm{U}-{ }^{14} \mathrm{C}\right]-$ or $\left[6-{ }^{14} \mathrm{C}\right]$ glucose by day-5 cultured rat blastocysts in the presence or absence of phenazin ethosulfate (PES) or excess of pyruvate

\begin{tabular}{|c|c|c|c|}
\hline $\begin{array}{l}\mathrm{PES}^{\mathrm{a}} \\
\left(\mathrm{mmol} \mathrm{l}^{-1}\right)\end{array}$ & $\begin{array}{c}{\left[6-{ }^{14} \text { C]glucose }{ }^{b}\right.} \\
\left(\text { pmol per embryo } h^{-1}\right)\end{array}$ & $\begin{array}{c}{\left[\mathrm{U}^{14} \mathrm{C} \text { C]glucose } \mathrm{b}^{\mathrm{b}}\right.} \\
\left(\text { pmol per embryo } \mathrm{h}^{-1}\right)\end{array}$ & $\begin{array}{l}{\left[\mathrm{U}-{ }^{14} \mathrm{C}\right] \text { glucose }} \\
\text { plus } 5 \mathrm{mmol} \text { pyruvate } 1^{-1} \\
\text { (pmol per embryo } \mathrm{h}^{-1} \text { ) }\end{array}$ \\
\hline 0 & $0.010 \pm 0.001$ & $1.62 \pm \frac{0.10}{(14)}$ & $0.81 \underset{(14)}{ \pm 0.04^{* * *}}$ \\
\hline 0.01 & $0.016 \pm \frac{ \pm 0.002^{*}}{(6)}$ & $15.3 \pm 0.63^{* *}$ & $16.5 \pm 1.07^{* *}$ \\
\hline
\end{tabular}

Values are given as means \pm SEM.

aPES was added at the end of the culture period $(24 \mathrm{~h})$ and was present throughout the incubation $(4 \mathrm{~h})$.

${ }^{b} \mathrm{Glucose}$ concentration was $0.28 \mathrm{mmol} \mathrm{l}^{-1}$ throughout the $4 \mathrm{~h}$ incubation.

Numbers in parentheses are the number of metabolic chambers of three embryos each.

${ }^{*} P<0.05$ versus 0 mmol PES $\mathrm{I}^{-3}$.

${ }^{* *} P<0.001$ versus 0 mmol PES $\mathrm{I}^{-1}$.

${ }^{* * *} P<0.001$ versus $\left[U^{14} \mathrm{C}\right]$ glucose without excess of pyruvate

Table 3. Effect of dinitrophenol (DNP) and insulin on $\left[1-{ }^{14} \mathrm{C}\right]$ pyruvate and $\left[5-{ }^{3} \mathrm{H}\right]$ glucose utilization by fresh, day -5 rat blastocysts

\begin{tabular}{|c|c|c|c|}
\hline $\mathrm{DNP}^{\mathrm{a}}$ & Insulin ${ }^{a}$ & $\begin{array}{c}{\left[1-^{14} \mathrm{C}\right] \text { pyruvate }} \\
\left(\text { pmol per embryo } \mathrm{h}^{-1}\right)\end{array}$ & $\begin{array}{c}{\left[5-{ }^{3} \mathrm{H}\right] \text { glucose } \mathrm{a}^{\mathrm{a}}} \\
\left(\text { pmol per embryo } \mathrm{h}^{-1}\right)\end{array}$ \\
\hline- & - & $2.00 \pm \underset{(19)^{b}}{0.18}$ & $13.0 \pm \frac{0.36}{(7)}$ \\
\hline+ & - & $\begin{array}{c}7.74 \pm 0.5^{*} \\
(20)\end{array}$ & $22.0 \pm \frac{ \pm}{(7)} 0.50^{*}$ \\
\hline- & + & $1.40 \pm 0.3$ & $12.9 \pm 0.84$ \\
\hline+ & + & ${ }_{(12)}^{6.30 \pm 0.5^{*}}$ & $25.2 \pm 0.13^{*}$ \\
\hline
\end{tabular}

Values given as means \pm SEM.

'DNP: 50 micromol $]^{-1}$; insulin: $600 \mathrm{pmol}^{-1}$; $\left[11^{-14} \mathrm{C}\right]$ pyruvate: $1 \mathrm{mmol} \mathrm{l} \mathrm{I}^{-1}$ and $\left[5-{ }^{3} \mathrm{H}\right]-$ glucose: $0.28 \mathrm{mmol}^{-1}$ were present throughout the incubation $(4 \mathrm{~h})$.

Numbers in parentheses are the number of metabolic chambers of three embryos each.

${ }^{*} P<0.001$ versus respective control without DNP.

that (I) $\left[\mathrm{U}_{-}{ }^{14} \mathrm{C}\right] \mathrm{glucose}$ yields six times more ${ }^{14} \mathrm{CO}_{2}$ per mole than $\left[6-{ }^{14} \mathrm{C}\right]$ glucose via complete oxidization in the Krebs cycle and (2) $\left[6-{ }^{14} \mathrm{C}\right] \mathrm{glucose}$ was oxidized through the Krebs cycle only, then only $4 \%$ of the $\mathrm{U}_{-}{ }^{14} \mathrm{C}$ glucose was oxidized through the cycle. Hence, $96 \%$ of $\left[\mathrm{U}-{ }^{14} \mathrm{C}\right]$ glucose was oxidized via other pathways.

The first is the formation of acetyl-CoA from pyruvate, through the action of the pyruvate dehydrogenase complex. The second is the pentose-phosphate pathway.

Phenazin ethosulfate (PES) increased ${ }^{14} \mathrm{CO}_{2}$ production from [U- ${ }^{14} \mathrm{C}$ ]glucose about tenfold and about 1.5 fold, from [6${ }^{14}$ Clglucose (Table 2), indicating that the pentose-phosphate pathway was active and responsive to stimulation. However, ${ }^{14} \mathrm{CO}_{2}$ production from $\left[\mathrm{U}^{14}{ }^{14} \mathrm{C}\right] \mathrm{glucose}$ was decreased in the presence of a sixfold increase in the concentration of unlabelled pyruvate in the incubation medium (Table 2), suggesting that the pyruvate dehydrogenase complex was responsible for part of the $\left[\mathrm{U}-{ }^{14} \mathrm{C}\right] \mathrm{g}$ lucose oxidation, at least in the basal condition.
In the presence of PES, the stimulated ${ }^{14} \mathrm{CO}_{2}$ production was not modified by excess pyruvate. Ignoring the possible participation of pyruvate dehydrogenase, and assuming that all the [U- ${ }^{14} \mathrm{C}$ lglucose was oxidized through the pentose-phosphate pathway, the maximal glucose oxidation rate through that pathway amounted to about $2 \%$ of the total glucose utilization rate (Table 1). PES increased glucose utilization rate through the pentose-phosphate pathway in a dose-dependent manner; up to at least ten times, at a concentration of $0.01 \mathrm{mmoll}^{-1}$ (from $0.53 \pm 0.04(n=12)$ to $5.1 \pm 0.20(n=14)$ pmol per embryo $\left.\mathrm{h}^{-1}\right)(P<0.001)$. However, $\left[5-{ }^{3} \mathrm{H}\right]$ glucose utilization (that is glycolysis) was depressed by about $50 \%$ (from $22.1 \pm 1.5(n=12)$ to $9.7 \pm 0.36(n=14)$ pmol per embryo $\left.h^{-1}\right)(P<0.001)$.

As Ham's FI0 medium contains pyruvate $\left(1 \mathrm{mmol} \mathrm{l}^{-1}\right)$, the oxidation of $\left[6-{ }^{14} \mathrm{Clglucose}\right.$ through the Krebs cycle might be underestimated by dilution of the endogenously produced $\left[{ }^{14} \mathrm{C}\right]$ pyruvate. The maximum dilution factor can be derived on the assumption that glucose metabolized through the glycolytic 


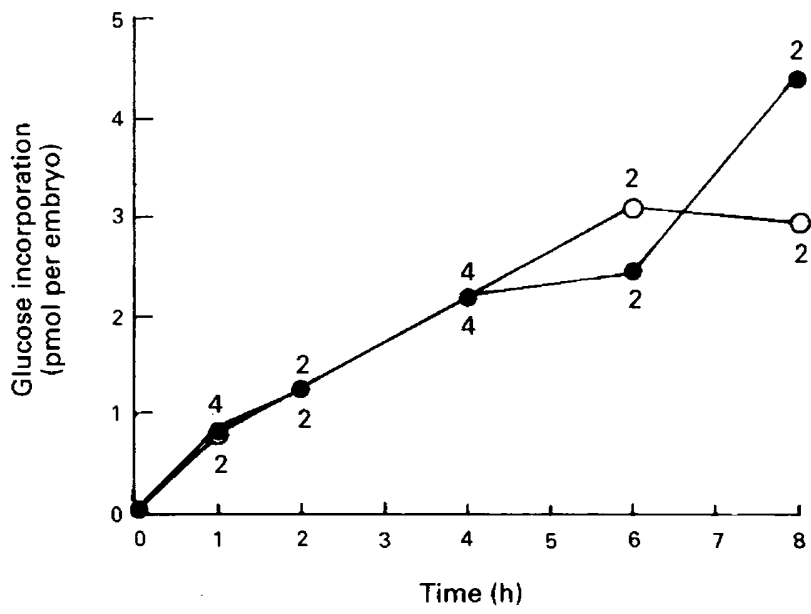

Fig. 3. Incorporation of $\left[{ }^{14} \mathrm{C}\right]$ labelled compounds (in terms of glucose) into day- 5 rat blastocysts cultured for $24 \mathrm{~h}$ and further incubated for 1 to $8 \mathrm{~h}$ in the presence of $0.28 \mathrm{mmol}\left[\mathrm{U}-{ }^{14} \mathrm{C}\right]$ glucose $\mathrm{I}^{-1}$, with $(O)$ or without $(1)$ insulin at a concentration of $600 \mathrm{pmol} \mathrm{l}^{-1}$. Each point is the mean \pm SEM of the indicated numbers of cells incubated from three embryos.

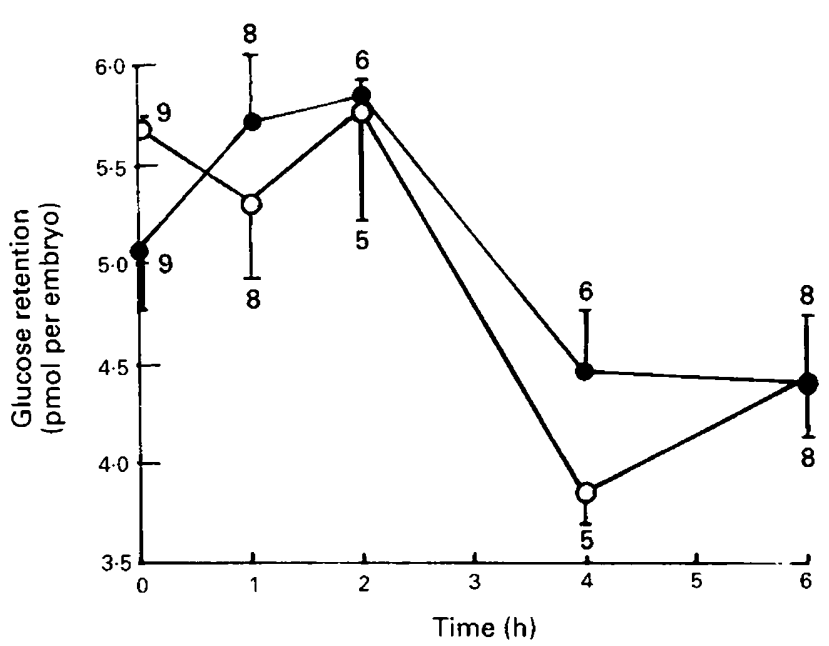

Fig. 4. Retention of $\left[{ }^{14} \mathrm{C}\right]$ labelled compounds (in terms of glucose) by day-5 rat blastocysts incubated in the presence of $0.28 \mathrm{mmol}$ $\left[\mathrm{U}_{-}{ }^{14} \mathrm{C}\right]$ glucose $\mathrm{l}^{-1}$ for $24 \mathrm{~h}$, with $(\mathrm{O})$ or without $(-)$ insulin $(600 \mathrm{pmol}$ $\left.1^{-1}\right)$, and further incubated for 1 to $6 \mathrm{~h}$ in the presence of $0.28 \mathrm{mmol}$ unlabelled glucose $\mathrm{l}^{-1}$, with (O) or without $(\mathrm{O}) 600$ pmol insulin $\mathrm{l}^{-1}$. Each point is the mean \pm SEM of indicated numbers of cells incubated from three embryos each.

pathway yields 1 mole of labelled pyruvate per mole of glucose (20.5 pmol per embryo $\mathrm{h}^{-1} \times 4 \mathrm{~h} \times 3$ embryos $=246 \mathrm{pmol}$ ), and from the amount of pyruvate present in $5 \mu \mathrm{l}$ of Ham's F10 ( $\left.1 \mathrm{mmoll}{ }^{-1} \times 5 \times 10^{-6} \mathrm{l}=5000 \mathrm{pmol}\right)$.

This dilution factor does not exceed 20. Taking this maximum dilution factor and the rate of ${ }^{14} \mathrm{CO}_{2}$ produced from $\left[6-{ }^{14} \mathrm{C}\right]$ glucose (Table 2), it can be calculated that glucose utilization through the Krebs cycle could account for no more than 0.2 pmol per embryo $\mathrm{h}^{-1}$, i.e. about $1 \%$ of the total glucose utilization in cultured blastocysts.

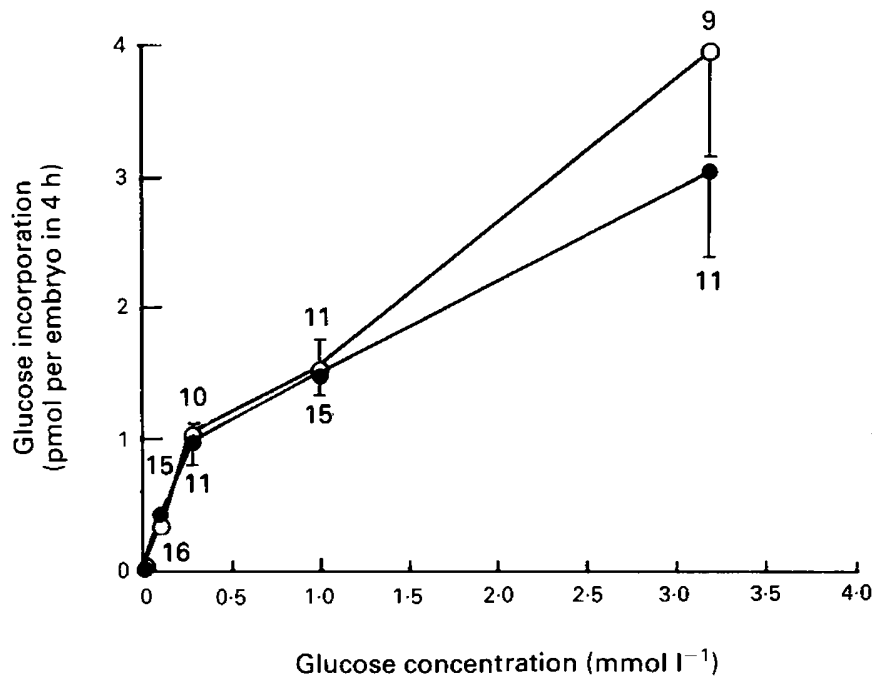

Fig. 5. Incorporation of $\left[{ }^{3} \mathrm{H}\right]$ labelled compounds (in terms of glucose) into day -5 rat blastocysts cultured for $24 \mathrm{~h}$ and further incubated with $\left[5-{ }^{3} \mathrm{H}\right]$ glucose at increasing concentrations, with $(\mathrm{O})$ or without $(O)$ 600 pmol insulin $1^{-1}$. Each point is the mean \pm SEM of the indicated numbers of cells incubated from three embryos each.

\section{$\left[1-{ }^{14}\right.$ C]pyruvate utilization}

Fresh embryos were incubated in the presence of $1 \mathrm{mmol}$ $\left[1-{ }^{14} \mathrm{C}\right.$ pyruvate $\mathrm{l}^{-1}$ and $\left[5-{ }^{3} \mathrm{H}\right]$ glucose $\left(0.28 \mathrm{mmol}^{-1}\right)$, with or without dinitrophenol (DNP) at a dose of $50 \mu \mathrm{moll}^{-1}$, and insulin $\left(600 \mathrm{pmol}^{-1}\right)$. Pyruvate was utilized at a rate of 2.0 pmol per embryo $\mathrm{h}^{-1}$ (Table 3 ), i.e. about $8 \%$ of the amount of pyruvate formed through the glycolytic pathway $(13 \times 2=$ $26 \mathrm{pmol}$ per embryo $\mathrm{h}^{-1}$ ) (Table 3). This value is at least eight times higher than the amount expected from the maximum calculated rate $(1 \%)$ of $\left[6-{ }^{14} \mathrm{C}\right]$ glucose utilization by the Krebs cycle (see above). DNP induced a fourfold activation of pyruvate oxidation, whereas glycolysis was stimulated only twofold. Insulin was without effect on pyruvate utilization in the presence, or absence, of DNP.

\section{Incorporation and retention of $\left[5-{ }^{3} \mathrm{H}\right]$ - or $\left[\mathrm{U}-{ }^{14} \mathrm{C}\right]$ glucose}

Incorporation of glucose-derived $\left[{ }^{3} \mathrm{H}\right]$ - or $\left[{ }^{14} \mathrm{C}\right]$-labelled compounds into cultured day-5 embryos was studied in relation to incubation time in the presence of $0.28 \mathrm{mmol}$ labelled glucose $1^{-1}$. There was a non-linear increase in ${ }^{14} \mathrm{C}$ incorporation, which levels off with increased incubation time (Fig. 3).

${ }^{3} \mathrm{H}$ incorporation rate was half that of ${ }^{14} \mathrm{C}$ incorporation at $4 \mathrm{~h}$ $(1.0 \pm 0.2(n=10)$ versus $2.1 \pm 0.2(n=15)$ pmol glucose equivalent per embryo) $(P<0.001)$.

Embryos, cultured for $24 \mathrm{~h}$ in the presence of $0.28 \mathrm{mmol}$ $\left[5-{ }^{3} \mathrm{H}\right]$ - and $\left[\mathrm{U}_{-}{ }^{14} \mathrm{C}\right]$ glucose $\mathrm{I}^{-1}$ incorporated slightly less ${ }^{3} \mathrm{H}$ than ${ }^{14} \mathrm{C}$ compounds $(3.6 \pm 0.3(n=9)$ versus $5.1 \pm 0.3(n=9)$ pmol per embryo) $(P<0.01)$.

Replacement of labelled with unlabelled glucose at the same concentration was followed by a slow and only partial release of incorporated ${ }^{14} \mathrm{C}$ (Fig. 4) and ${ }^{3} \mathrm{H}$ (not shown). Insulin had no effect on the incorporation kinetics, or on the retention of glucose-derived labelled compounds (Figs 3 and 4). 
Table 4. Glucose utilization by day-5 blastocysts from diabetic rats

\begin{tabular}{|c|c|c|c|c|}
\hline & \multicolumn{2}{|c|}{$\begin{array}{c}{\left[5^{3} \mathrm{H}\right] \text { glucose } \mathrm{e}^{\mathrm{a}}} \\
\text { (pmol per embryo } \mathrm{h}^{-1} \text { ) }\end{array}$} & \multicolumn{2}{|c|}{$\begin{array}{c}{\left[\mathrm{U}^{14}{ }^{14} \mathrm{C} \text { lglucose } \mathrm{a}^{\mathrm{a}}\right.} \\
\text { (pmol per embryo } \mathrm{h}^{-1} \text { ) }\end{array}$} \\
\hline & $\begin{array}{l}\text { Fresh } \\
\text { embryos }\end{array}$ & $\begin{array}{l}\text { Cultured } \\
\text { embryos }\end{array}$ & $\begin{array}{l}\text { Fresh } \\
\text { embryos }\end{array}$ & $\begin{array}{l}\text { Cultured } \\
\text { embryos }\end{array}$ \\
\hline Control rats & $\begin{array}{c}12.5 \pm 0.5 \\
(17)^{\mathrm{b}}\end{array}$ & $20.4 \underset{(8)}{ \pm} 0.5^{*}$ & $0.24 \underset{(17)}{ \pm} 0.02$ & $0.60 \underset{(8)}{ \pm} 0.04^{*}$ \\
\hline Diabetic rats & $11.5 \pm \underset{(17)}{0} 0.36$ & $20.8 \pm \underset{(8)}{ \pm} 0.5^{*}$ & $0.26 \pm 0.02$ & $0.49 \underset{(8)}{ \pm} 0.03^{*}$ \\
\hline
\end{tabular}

Values given as means $\pm \mathrm{SEM}$.

${ }^{a}$ Glucose concentration was $0.28 \mathrm{mmol} \mathrm{I}^{-1}$ throughout the $4 \mathrm{~h}$ incubation.

b Numbers in parentheses are the number of metabolic chambers of three embryos each.

${ }^{*} P<0.001$ versus fresh embryo.

The incorporation of $\left[5-{ }^{3} \mathrm{H}\right]$ glucose was also studied as a function of glucose concentration in the medium. A biphasic curve was obtained (Fig. 5) that was similar to that obtained for glucose utilization (Fig. 1), with a break point at $0.28 \mathrm{mmol}^{-1}$. Insulin had no effect at low or high glucose concentrations.

\section{Glucose utilization by fresh and cultured blastocysts from diabetic} rats

Day 5 blastocysts from diabetic rats showed a normal glucose utilization rate before (fresh) and after (cultured) a $24 \mathrm{~h}$ culture period (Table 4).

\section{Discussion}

Using a non-invasive technique for measuring substrate consumption, Brison and Leese (1991) showed that rat blastocysts used glucose as their main source of energy, and that glycolysis is the main metabolic pathway, acounting for almost all of the glucose consumed. Lactate production was quantitatively equivalent to the amount of glucose taken up by the embryo on a 2 to 1 molar basis. In the present work, we determined the rate of glycolysis by measuring the production of ${ }^{3} \mathrm{H}_{2} \mathrm{O}$ from $\left[5-{ }^{3} \mathrm{H}\right]$ glucose, and obtained values similar to those reported by Brison and Leese. Fresh embryos used about 11.5 pmol glucose per embryo $\mathrm{h}^{-1}$; a figure similar to that reported by Brison and Leese (1991) in rats, but about three times higher than measurements made in mice (Gardner and Leese, 1988), and less than half the glucose consumption rate reported for human blastocysts (Hardy et al., 1989). After culture for $24 \mathrm{~h}$ when the cell population had approximately doubled (De Hertogh et al., 1991), the glucose consumption by rat blastocysts through glycolysis amounted to $20.4 \mathrm{pmol}$ per embryo $h^{-1}$, showing a close relationship between cell population and glucose consumption.

A curvilinear relationship was observed between glucose consumption via glycolysis and glucose concentration in the medium. A sharp increase was observed up to about $0.28 \mathrm{mmol}$ glucose $1^{-1}$, followed by a slow, linear increase up to $10 \mathrm{mmoll}^{-1}$. The slope of this curve was similar to that described for glucose uptake by mouse blastocysts (Gardner and Leese, 1988). The fast part corresponds to a rapidly saturable metabolic process, with an apparent $K_{\mathrm{t}}$ as low as $0.17 \mathrm{mmol} \mathrm{l}^{-1}$ and a $V_{\max }$ of about 23 pmol per embryo $\mathrm{h}^{-1}$ in cultured blastocysts. The $K_{\mathrm{t}}$ value is similar to that described for mouse blastocysts and is in the range of $K_{\mathrm{m}}$ values for some of the glycolytic enzymes (Lehninger, 1982; Rawn, 1989).

Hence, glucose utilization via glycolysis is rapidly saturated at low extra-embryonic glucose concentrations, such that higher glucose concentrations (up to $10 \mathrm{mmol}^{-1}$ ) would increase glucose consumption by only about $40 \%$. Blocking the $\mathrm{Na}^{+}$. independent glucose-transport mechanism with phloretin completely abolished the rapid component of glucose utilization, as also shown in mice (Gardner and Leese, 1988), indicating the presence of facilitated glucose transport in rat blastocysts. In agreement with observations made in other species (Gardner and Leese, 1988; Robinson et al., 1990), this transport system is not dependent on insulin, as shown by the lack of activation by this hormone of either the first or second component of the glucose consumption kinetics.

Insulin-dependent glucose transporter (Glut-1 and Glut-2) gene expressions have recently been described in mouse blastocysts. The Glut-4 isoform, which is insulin dependent, is not expressed (Hogan et al., 1991). The present study suggests that there is a similar insulin-independent glucose transport in rat blastocysts. However, formal characterization of the transporter isoforms has not yet been described in rats.

Glucose oxidation was also studied by ${ }^{14} \mathrm{CO}$, production from labelled precursors. A minimal release of ${ }^{14} \mathrm{CO}_{2}$ was observed from $\left[6-{ }^{14} \mathrm{C}\right]$ glucose indicating a very low oxidation of glucose via the Krebs cycle. Taking into account the maximum dilution of endogenously produced $\left[{ }^{14} \mathrm{C}\right]$ pyruvate by unlabelled pyruvate present in the medium, glucose oxidation via the Krebs cycle did not exceed $1 \%$ of total glucose consumption in cultured blastocysts. These results agree with those of Brison and Leese (1991), who accounted for almost $100 \%$ of glucose consumption as lactate formation.

However, when $\left[{ }^{14} \mathrm{C}\right]$ pyruvate was used in the incubation medium, a much higher ${ }^{14} \mathrm{CO}_{2}$ production was observed with fresh embryos, amounting to about $2.0 \mathrm{pmol}$ per embryo $\mathrm{h}^{-1}$, that is, about $8 \%$ of the amount of glucose metabolized through 
glycolysis, and thus likely to produce pyruvate. This discrepancy between ${ }^{14} \mathrm{CO}_{2}$ production from $\left[6-{ }^{14} \mathrm{C}\right]$ glucose and from $\left[{ }^{14} \mathrm{C}\right]$ pyruvate could be explained if the products of glycolysis were not able to enter the tricarboxylic cycle. Such a situation has been reported in cattle blastocysts by Rieger and Guay (1988), who suggest a block at the pyruvate kinase level, i.e. the last glycolytic step before pyruvate formation. This hypothesis however diverges from the observations of Brison and Leese (1991), in which lactate accumulated in rat blastocysts incubated in the presence of glucose. Another explanation could be that endogenously produced pyruvate is unable to equilibrate with extracellular pyruvate and fails to gain access to the oxidative pathways. A third possibility is that oxidation of $\left[1-{ }^{14} \mathrm{C}\right]$ pyruvate is restricted to the activity of the pyruvate dehydrogenase complex leading to the formation of acetyl $\mathrm{CoA}$ and ${ }^{14} \mathrm{CO}_{2}$. This hypothesis is supported by our observations of $\left[\mathrm{U}^{14}{ }^{14} \mathrm{Clglucose}\right.$ metabolism, showing that ${ }^{14} \mathrm{CO}_{2}$ production slightly decreased when pyruvate concentration in the incubation medium was increased, probably as a result of dilution of the $\left[1_{-}{ }^{14} \mathrm{C}\right]$ pyruvate produced via the glycolytic pathway. The activity of the Krebs cycle, although limited in basal conditions, could be stimulated, as shown by increased ${ }^{14} \mathrm{CO}_{2}$ production from $\left[1-{ }^{14} \mathrm{C}\right.$ ]pyruvate in the presence of DNP, as previously observed in cattle blastocysts by Rieger and Guay (1988). Insulin, however, did not influence pyruvate utilization in the presence or absence of DNP.

A limited amount of glucose may be utilized via the pentosephosphate shunt as shown in mouse ( $\mathrm{O}^{\prime}$ Fallon and Wright, 1987) and pig (Flood and Wiebold, 1988) blastocysts. We obtained a similar result for rat blastocysts using $\left[\mathrm{U}-{ }^{14} \mathrm{C}\right.$ glucose as a precursor; a maximum of $2 \%$ of the total glucose used was oxidized via the pentose-phosphate pathway. Phenazin ethosulfate (PES) stimulated this cycle at least tenfold, despite an overall $50 \%$ decrease in glycolysis. The latter effect has also been described in other species (O'Fallon and Wright, 1987; Flood and Wiebold, 1988) and may be due to the nonspecific toxic effect of PES on the embryos. The morphological appearance of the embryos had deteriorated after $4 \mathrm{~h}$ incubation in the presence of $0.01 \mathrm{mmol}$ PES $\mathrm{l}^{-1}$. It has been shown in mouse embryos, that PES, at a tenfold higher concentration $\left(0.1 \mathrm{mmol} \mathrm{l}^{-1}\right)$, induces non-enzymatic decarboxylation of pyruvate, thereby giving an apparent rise in the pentosephosphate shunt activity and decreasing glycolysis by removing $\mathrm{NAD}^{+}$(O'Fallon and Wright, 1991). Whether such a mechanism plays a role in rat embryos at the much lower PES concentration used here is unknown. However, increasing the concentration of pyruvate in the medium decreased ${ }^{14} \mathrm{CO}_{2}$ production in the basal, but not in the PES-stimulated, state, strongly suggesting that PES was able to induce glucose oxidation through a mechanism not dependent on exogenous pyruvate, i.e. the pentose-phosphate shunt. Our experiments thus show that the pentose-phosphate pathway was operating at a submaximal rate and could be stimulated though not by insulin.

Previous experiments (De Hertogh et al., 1991) showed that rat blastocysts can develop in vitro in glucose-free Ham's F-10 medium, although to a slightly lesser extent than in Ham's F-10 containing $5.5 \mathrm{mmol}$ glucose $\mathrm{l}^{-1}$. Hence, alternative sources of energy can be used by blastocysts. One of them, might be glutamine. However, all our experiments were performed in the same concentration of glutamine, thus allowing a valid comparison between groups. Another could be external pyruvate, as shown in the present study. Pyruvate, if fully oxidized in the tricarboxylic cycle, would yield almost eight times more ATP per mmol than glucose metabolized via the glycolytic pathway. Considering that fresh embryos utilize about six times more glucose than pyruvate ( 13 versus 2 pmol per embryo $h^{-1}$ ), energy production could still be 1.5 times higher from pyruvate than from glucose. However, as discussed earlier, the present work does not allow a clearcut estimate of the amount of pyruvate oxidized in the Krebs cycle, beyond the pyruvate dehydrogenase step and acetyl CoA formation. This first metabolic step per se would yield only $20 \%$ of the extra energy, if not followed by the high energy producing oxidative steps of the tricarboxylic cycle (Rawn, 1989).

Besides its role as an energy source, glucose or glucose-derived carbon atoms might be incorporated into macromolecules such as glycogen, lipids, nucleic acids or proteins (Murdoch and Wales, 1973; Flynn and Hillman, 1978; Pike and Wales, 1982; Eridisinghe et al., 1984). In rabbit embryos, glucose may be used more as an anabolic compound than as an energy source (Robinson and Benos, 1991). Insulin could stimulate such incorporation, and eventually play an important role in anabolic processes (Wales et al., 1985).

We investigated this problem, by studying the total incorporation of glucose-derived $\left[{ }^{3} \mathrm{H}\right]$ - or $\left[{ }^{14} \mathrm{C}\right]$-labelled substrate into rat blastocysts. We showed that accumulation of radioactivity increased slowly with incubation time with a plateau of about $5 \mathrm{pmol}$ per embryo after $24 \mathrm{~h}$ in culture. This amount is very small compared with the total glucose utilization during that time. Hence, considering that fresh blastocysts use about 11.5 pmol per embryo $\mathrm{h}^{-1}$ and consumption is about $20.4 \mathrm{pmol}$ per embryo $\mathrm{h}^{-1}$ after $24 \mathrm{~h}$ of culture, we may conclude that glucose utilization during the whole incubation time is between $276(11.5 \times 24)$ and $490(20.4 \times 24)$ pmol per embryo. Glucosederived labelled products incorporated into the embryo therefore amounted to less than 1 to $2 \%$ of this consumption. The nature of the accumulated products was not determined. However, ${ }^{14} \mathrm{C}$ was incorporated to a slightly greater extent than ${ }^{3} \mathrm{H}$, suggesting that most of the glucose retained in the embryo did not follow the glycolytic pathway.

It has been shown in other species that glycogen may constitute most of the retained glucose (Kaye, 1986), and this observation fits in with our results. A small amount of carbon, derived from glucose oxidation products, is also accumulated, but accounts for much less than $1 \%$ of the total glucose consumption.

Retention kinetics showed that $\left[{ }^{3} \mathrm{H}\right]$ glucose was incorporated as a function of glucose concentration in a curvilinear relationship, similar to that of glucose utilization. Hence, a common mechanism may control utilization and accumulation of glucose above a concentration of $0.28 \mathrm{mmoll}^{-1}$ in the medium. The slower part of the retention kinetics was however depressed less than that of the consumption kinetics, suggesting that another step, beyond glucose-6-phosphate, might be involved in limiting glucose utilization but allowing a relatively higher retention rate. Accumulation of glucose-derived molecules may proceed to a relatively higher amount at high glucose concentration, even though glucose consumption remains very much the same. Another aspect of the glucose-derived products, is their slow turnover as shown by the pulse-chase experiments in 
which unlabelled glucose was substituted for labelled glucose in the medium. In $6 \mathrm{~h}$, while the overall glucose utilization amounted to about 122 pmol per embryo $(6 \times 20.4 \mathrm{pmol}$ per embryo $\mathrm{h}^{-1}$ ), less than $1 \mathrm{pmol}$ of labelled product (in terms of labelled glucose) was released. This ruled out the possibility that retained products were either labelled glucose itself or breakdown products, and suggests that the glucose-derived label had been incorporated into slow turnover pools of macromolecules, most of which retain the intact glucose structure. A slow turnover of glycogen has been described in other species (Kaye, 1986). Insulin was without effect, either on the incorporation kinetics, retention concentrations or the turnover kinetics of $\left[{ }^{3} \mathrm{H}\right]$ or $\left[{ }^{14} \mathrm{C}\right]$ labelled products. Hence, we were unable to show an effect of insulin on the gross incorporation of glucosederived metabolites into the embryo, although more discrete insulin effects on proteins or nucleic acids cannot be ruled out (Wales et al., 1985).

Blastocysts from diabetic mothers were shown to use glucose at a similar rate to blastocysts from normal mothers. A similar observation was reported recently by Brison and Leese (1990). However, we discarded blastocysts showing signs of degeneration to compare structures of similar appearance. We may thus conclude that apparently healthy blastocysts, from diabetic mothers, put into a similar medium to normal blastocysts, can utilize glucose at a normal rate.

In conclusion, the present work shows that glucose is taken up by a carrier-mediated mechanism in rat blastocysts, and metabolised predominantly through glycolysis. The Krebs cycle and pentose-phosphate pathways, although active, account for less than 1 and $2 \%$, respectively, of the total glucose consumption, which is rapidly saturated at glucose concentrations as low as $0.28 \mathrm{mmol} \mathrm{l}^{-1}$. At higher concentrations, glucose consumption changes only minimally, although incorporation into macromolecules is increased, and could be involved in the toxic effect that high glucose concentrations have on blastocyst growth (De Hertogh et al., 1991).

The observed growth anomalies described in blastocysts from diabetic mothers (Vercheval et al., 1990) are unlikely to be mediated by significant changes in glucose metabolism, unless abnormal accumulation of glucose-derived products plays a role, as yet to be defined.

The significant effect of insulin on blastocyst growth observed by De Hertogh et al. (1991) does not result from any gross modification of glucose uptake, metabolism or incorporation.

The authors are indebted to the Fonds de la Recherche Scientifique Médicale of Belgium and the Fonds de Développement Scientifique of the University of Louvain-La-Neuve who supported this project and to A. M. Delait and S. Depreester who prepared the manuscript and figures.

\section{References}

Beebe LFS and Kaye PL (1991) Maternal diabetes and retarded pre-implantation development of mice Diabetes $\mathbf{4 0} 457-461$

Brison DR and Leese HJ (1990) Glucose uptake by embryos from diabetic rats journal of Reproduction and Fertility Abstract Series 6 Abstract 71

Brison DR and Leese HJ (1991) Energy metabolism in late preimplantation rat embryos Journal of Reproduction and Fertility 93 245-25I
Brown JJG and Whittingham DG (1991) The roles of pyruvate, lactate and glucose during preimplantation development of embryos from $F_{1}$ hybrid mice in vitro Development 112 99-105

De Hertogh R, Ekka E and Vanderheyden I (1982) Estrogen receptor and stimulation of uterine protein synthesis in ovariectomized diabetic rats infused with $17 \beta$-estradiol Endocrinology $110741-748$

De Hertogh R, Vercheval M, Pampfer S, Vanderheyden I, De Bernardi P and Michiels B (1989) Experimental diabetes interferes with the early development of rat embryo in the pre-implantation period Diabetologia $32480 \mathrm{~A}$

De Hertogh R, Vanderheyden I, Pampfer S, Robin D, Dufrasne E and Delcourt J (1991) Stimulatory and inhibitory effects of glucose and insulin on rat blastocyst development in vitro Diabetes 40 641-647

De Hertogh R, Vanderheyden I, Pampfer S, Robin D, Delcourt J (1992) Maternal insulin treatment improves pre-implantation embryo development in diabetic rats Diabetologia 35 406-408

Diamond MP, Moley KH, Pellicer A, Vaughn WK and DeCherney AH (1989) Effects of streptozotocin- and alloxan-induced diabetes mellitus on mouse follicular and early embryo development Journal of Reproduction and Fertility $861-10$

Edirisinghe WR, Wales RG and Pike IL (1984) Synthesis and degradation of labelled glycogen pools in preimplantation mouse embryos during short periods of in vivo culture Australian Journal of Biological Sciences 37 137-146

Eriksson UJ (1984) Congenital malformations in diabetic animal models - a review Diabetes Research $156-66$

Flood MR and Wiebold JL (1988) Glucose metabolism by preimplantation pig embryos Journal of Reproduction and Fertility 84 7-12

Flynn T] and Hillman N (1978) Lipid synthesis from $\left[\mathrm{U}-{ }^{14} \mathrm{Clglucose}\right.$ in preimplantation mouse embryos in culture Biology of Reproduction $19922-926$

Gardner HG and Kaye PL (1984) Effects of insulin on preimplantation mouse embryos Australian Society for Reproduction and Biology 16107

Gardner HG and Leese HJ (1988) The role of glucose and pyruvate transport in regulating nutrient utilization by preimplantation mouse embryos Development 104 423-429

Hardy K, Hooper MAK, Handyside AH, Rutherford AJ, Winston RML and Leese HJ (1989) Non-invasive measurement of glucose and pyruvate uptake by individual human oocytes and preimplantation embryos Human Reproduction $4188-191$

Harvey MB and Kaye PL (1988) Insulin stimulates protein synthesis in compacted mouse embryos Endocrinology 122 1182-1184

Harvey MB and Kaye PL (1990) Insulin increases the cell number of the inner cell mass and stimulates morphological development of mouse blastocysts in vitro Development $110963-967$

Heyner S, Rao LV, Jarett L and Smith RM (1989) Preimplantation mouse embryos internalize maternal insulin via receptor-mediate endocytosis: pattern of uptake and functional correlations Developmental Biology 134 48-58

Hogan A, Heyner S, Charron MJ, Copeland NG, Gilbert DJ, Jenkins NA, Thorens $B$ and Schultz GA (1991) Glucose transporter gene expression in early mouse embryos Development $113363-372$

Kaye PL (1986) Metabolic aspects of the physiology of the preimplantation embryo. In Expermental Approaches to Mammalian Embryonic Development, pp 267-292 Eds J Rossant and RA Pederson. Cambridge University Press, Cambridge

Leese HJ and Barton AM (1984) Pyruvate and glucose uptake by mouse ova and preimplantation embryos Joumal of Reproduction and Fertility 72 9-13

Lehninger AL (1982) Principles of Biochemistry p 216. Worth Publishers Inc, New York

Murdoch RN and Wales RG (1973) Incorporation of $\left[{ }^{14} \mathrm{C}\right]$ glucose and $\left[{ }^{3} \mathrm{H}\right]$ uridine into the major classes of RNA in mouse embryos during preimplantation development Australian Journal of Biological Sciences 26 889-901

O'Fallon JV and Wright RW (1986) Quantitative determination of the pentose phosphate pathway in preimplantation mouse embryos Biology of Reproduction $3458-64$

O'Fallon JV and Wright RW (1987) Calculation of the pentose phosphate and Embden-Myerhoff pathways from a single incubation with $\left[\mathrm{U}-{ }^{14} \mathrm{C}\right]-$ and $\left[5-{ }^{-} \mathrm{H}\right] g$ lucose Analytical Biochemistry $162 \quad 33-38$

O'Fallon JV and Wright RW (1991) Methyl viologen as a preferred electron acceptor in metabolic experiments Analytical Biochemistry 198 179-183

Pampfer S, De Hertogh R, Vanderheyden I, Michiels B and Vercheval M (1990) Decreased inner cell mass proportion in blastocysts from diabetic rats Diabetes $39471-476$

Pike IL and Wales RG (1982) Uptake and incorporation of glucose especially into the glycogen pools of preimplantation mouse embryos during culture in vitro Australian Journal of Biological Sciences 35 195-206 
Rawn JD (1989) Biochemistry p 172. Neil Patterson Publishers, Burlington (NC) Rieger D \& Guay P (1988) Measurement of the metabolism of energy substrates in individual bovine blastocysts Joumal of Reproduction and Fertility $\mathbf{8 3}$ 585-591

Robinson DH, Smith PR and Benos DJ (1990) Hexose transport in preimplantation rabbit blastocysts Journal of Reproduction and Fertility 89 1-11

Robinson DH and Benos DJ (1991) Glucose metabolism in the trophectoderm and inner cell mass of the rabbit embryo Journal of Reproduction and Fertility $91493-499$
Rosenblum IY, Mattson BA and Heyner S (1986) Stage-specific insulin binding in mouse preimplantation embryos Developmental Biology 116 261-263

Vercheval M, De Hertogh R, Pampfer S, Vanderheyden I, Michiels B, De Bernardi P and De Meyer R (1990) Experimental diabetes impairs rat embryo development during the preimplantation period Diabetologia 33 187-191

Wales RG, Khurana NK, Edirisinghe WR and Pike IL (1985) Metabolism of glucose by preimplantation mouse embryos in the presence of glucagon insulin, epinephrine, cAMP, theophylline and caffeine Australian Journal of Biological Sciences 38 421-428 